\title{
HEMODIAPERFUSION IN LEPTOSPIROSIS
}

\author{
Galya Gancheva, Penka Ilieva, Maria Atanasova, Chrisima Tzvetanova, Iskra Simova \\ Department of Infectious Diseases, Epidemiology, Parasitology, and Tropical \\ Medicine, Medical University, Pleven, Bulgaria
}

\begin{abstract}
:
Comparatively have been studied laboratory parameters in severe cases of leptospirosis divided in two groups with and without hemodiaperfusion (HD). The dynamical investigations of blood urea nitrogen (BUN), serum creatinine, and serum bilirubin levels reveal that hemodiaperfusion markedly decreases the levels of nitrogen parameters and is non effective for serum bilirubin. Hemodiaperfusion in oliguric phase of the acute renal failure of leptospirosis prevents brain edema and lung edema - significant tanatogenic factors.
\end{abstract}

Key words: hemodiaperfusion, leptospirosis, acute renal failure, blood urea nitrogen, serum creatinine, serum bilirubin.

Leptospirosis is an acute infectious disease with multiorgan disorders. Acute renal failure and impaired hepatic functions are important clinical syndromes requiring multidisciplinary approach in the treatment including hemodiaperfusion (HD) $[1,2,4,5,6,7,8]$.

AIM of this study is evaluation of effects of HD in severe cases of leptospirosis.

\section{MATERIALAND METHODS:}

Clinical and laboratory parameters have been studied retrospectively and prospectively in 84 cases with leptospirosis treated in Clinic of Infectious Diseases - Pleven (1982 to 2004).

\section{RESULTS AND DISCUSSION:}

Using clinical and laboratory criteria characteristic for renal, hepatic, cardiovascular disorders and hemorrhagic syndrome has been evaluated the severity of the observed cases. Mild course (serum creatinine level below $200 \mu \mathrm{mol} / \mathrm{L}$ ) in $52,38 \%$ of cases, moderate (serum creatinine level between 200 and $600 \mu \mathrm{mol} / \mathrm{L}$ ) in $19,05 \%$, and severe course (serum creatinine level above $600 \mu \mathrm{mol} / \mathrm{L}$ ) in $28,57 \%$ have been established. The mortality is $14 \%$. The illness is with acute onset with fever above $38^{\circ} \mathrm{C}(100 \%)$, nausea with vomiting and diarrhea ( $86,90 \%$ and $21,43 \%$, respectively), and oligoanuria $(75 \%)$.
The physical examination reveals hepatomegaly $(100 \%)$, splenomegaly $(100 \%)$, jaundice $(75 \%)$, cardiovascular disorders - tachycardia $(59,52 \%)$, hypotension $(33,33 \%)$, toxical myocarditis $(20,24 \%)$, cardiac arrhythmias $(11,90 \%)$; hemorrhagic syndrome $(30,95 \%)$, and pulmonary disorders $(19,05 \%)$. Stiffness occurs in $11,90 \%$.

Routine laboratory parameters: leucocytosis in $73,81 \%$ (av. 14,9 . 10/2) with neutrophilia and left shift of granulocytes in $97,62 \%$, increased erythrocytes' sedimentation rate in $86,90 \%$ (av. in first hour $51 \mathrm{~mm}$ ), anemia in 73,81\%, thrombocytopenia in $42,86 \%$, increased fibrinogen in $73,81 \%$ (av. 6,4 g/L). Decreased total protein (in 29,76\%; av. 65,4 g/L), and serum albumins $(44,05 \%$; av. $37 \mathrm{~g} / \mathrm{L})$ have been established.

Blood urea nitrogen (BUN) level above $8,3 \mathrm{mmol} / \mathrm{L}$ is established in $80,95 \%$ of cases (av. $26,1 \mathrm{mmol} / \mathrm{L}$ ), and serum creatinine level above $135 \mu \mathrm{mol} / \mathrm{L}$ - in 72,62\% (av. 303,2 $\mu \mathrm{mol} /$ $\mathrm{L}$; with range from 74 to $860 \mu \mathrm{mol} / \mathrm{L}$ ). The serum bilirubin level is elevated in 70,24\% (av. 167,9 $\mu \mathrm{mol} / \mathrm{L}$ ). Serum transaminases levels are moderate elevated in $73,81 \%$ and range from normal to $382 \mathrm{U} / \mathrm{L}$ (av. $92 \mathrm{U} / \mathrm{L})$.

The patients have been treated with penicillin $(94,05 \%)$, ceftriaxon $(5,95 \%)$, in $11,90 \%$ of cases second antimicrobial course with zinacef or cefperazone. Pathogenical treatment includes adequate of urine output infusions of fluids $(100 \%)$, corticoids (48,81\%), diuretics (75\%), and transfusion of blood products $(52,38 \%)$. Hemodiaperfusion in oliguric phase of acute renal failure is administered in $19,05 \%$ of cases ( $32 \%$ of severe cases).

Dynamically are compared the followed laboratory parameters:

Table 1. BUN levels in group without and group with HD.

\begin{tabular}{|c|c|c|c|}
\hline $\begin{array}{c}\text { BUN } \\
(\mathrm{mmol} / \mathrm{L})\end{array}$ & $\begin{array}{c}\text { admission } \\
\text { (av.) }\end{array}$ & $\begin{array}{c}\text { in course } \\
\text { (av.) }\end{array}$ & $\begin{array}{c}\text { finally } \\
\text { (av.) }\end{array}$ \\
\hline without HD & 37 & 40 & 28 \\
\hline with HD & 39 & 44 & 30 \\
\hline $\mathrm{p}$ & $>0,10$ & $>0,10$ & $>0,10$ \\
\hline
\end{tabular}


Table 2. BUN levels in survivors and fatal cases (compared averages between cases without and with HD).

\begin{tabular}{|c|c|c|c|}
\hline $\begin{array}{c}\text { BUN } \\
\text { (mmol/L) }\end{array}$ & $\begin{array}{c}\text { admission } \\
\text { (av.) }\end{array}$ & $\begin{array}{c}\text { in course } \\
\text { (av.) }\end{array}$ & $\begin{array}{c}\text { finally } \\
\text { (av.) }\end{array}$ \\
\hline $\begin{array}{c}\text { without HD- } \\
\text { survivors }\end{array}$ & 31 & 32 & 17 \\
\hline $\begin{array}{c}\text { without HD- } \\
\text { fatal cases }\end{array}$ & 43 & 52 & 63 \\
\hline $\mathrm{p}$ & $>0,10$ & $>0,01$ & $<0,01$ \\
\hline $\begin{array}{c}\text { with HD- } \\
\text { survivors }\end{array}$ & 39,6 & 42,5 & 6,6 \\
\hline $\begin{array}{c}\text { with HD- } \\
\text { fatal cases }\end{array}$ & 39 & 45,7 & 61,1 \\
\hline $\mathrm{p}$ & $>0,10$ & $>0,01$ & $<0,01$ \\
\hline
\end{tabular}

Table 3. Serum creatinine levels in group without and group with HD.

\begin{tabular}{|c|c|c|c|}
\hline $\begin{array}{c}\text { creatinine } \\
(\mu \mathrm{mol} / \mathrm{L})\end{array}$ & $\begin{array}{c}\text { admission } \\
\text { (av.) }\end{array}$ & $\begin{array}{c}\text { in course } \\
\text { (av.) }\end{array}$ & $\begin{array}{c}\text { finally } \\
\text { (av.) }\end{array}$ \\
\hline without HD & 376 & 418 & 196 \\
\hline with HD & 685 & 603 & 314 \\
\hline $\mathrm{p}$ & $<0,001$ & $0,10>\mathrm{p}>0,05$ & $>0,10$ \\
\hline
\end{tabular}

Table 4. Serum creatinine levels in survivors and fatal cases (compared averages between cases without and with $\mathrm{HD})$.

\begin{tabular}{|c|c|c|c|}
\hline $\begin{array}{c}\text { creatinine } \\
(\mu \mathrm{mol} / \mathrm{L})\end{array}$ & $\begin{array}{c}\text { admission } \\
(\mathrm{av} .)\end{array}$ & $\begin{array}{c}\text { in course } \\
(\mathrm{av} .)\end{array}$ & $\begin{array}{c}\text { finally } \\
(\mathrm{av} .)\end{array}$ \\
\hline $\begin{array}{c}\text { without HD- } \\
\text { survivors }\end{array}$ & 387 & 420 & 98 \\
\hline $\begin{array}{c}\text { without HD- } \\
\text { fatal cases }\end{array}$ & 362 & 416 & 371 \\
\hline $\mathrm{p}$ & $>0,10$ & $>0,01$ & $<0,001$ \\
\hline $\begin{array}{c}\text { with HD- } \\
\text { survivors }\end{array}$ & 767 & 628 & 115 \\
\hline $\begin{array}{c}\text { with HD- } \\
\text { fatal cases }\end{array}$ & 604 & 578 & 580 \\
\hline $\mathrm{p}$ & $<0,05$ & $>0,10$ & $<0,001$ \\
\hline \multicolumn{2}{|r|}{} & & \\
\hline
\end{tabular}

Table 5. Serum bilirubin levels in group without and group with HD.

\begin{tabular}{|c|c|c|c|}
\hline $\begin{array}{c}\text { bilirubin } \\
(\mu \mathrm{mol} / \mathrm{L})\end{array}$ & $\begin{array}{c}\text { admission } \\
(\mathrm{av} .)\end{array}$ & $\begin{array}{c}\text { in course } \\
(\mathrm{av} .)\end{array}$ & $\begin{array}{c}\text { finally } \\
(\mathrm{av} .)\end{array}$ \\
\hline without HD & 224 & 332 & 206 \\
\hline with HD & 352 & 549 & 383 \\
\hline $\mathrm{p}$ & $>0,10$ & $>0,10$ & $>0,10$ \\
\hline
\end{tabular}

Table 6. Serum bilirubin levels in survivors and fatal cases (compared averages between cases without and with $\mathrm{HD})$.

\begin{tabular}{|c|c|c|c|}
\hline $\begin{array}{c}\text { bilirubin } \\
(\mu \mathrm{mol} / \mathrm{L})\end{array}$ & $\begin{array}{c}\text { admission } \\
\text { (av.) }\end{array}$ & $\begin{array}{c}\text { in course } \\
\text { (av.) }\end{array}$ & $\begin{array}{c}\text { finally } \\
\text { (av.) }\end{array}$ \\
\hline $\begin{array}{c}\text { without HD- } \\
\text { survivors }\end{array}$ & 194 & 522 & 69 \\
\hline $\begin{array}{c}\text { without HD- } \\
\text { fatal cases }\end{array}$ & 306 & 455 & 455 \\
\hline $\mathrm{p}$ & $>0,10$ & $>0,01$ & $<0,05$ \\
\hline $\begin{array}{c}\text { with HD- } \\
\text { survivors }\end{array}$ & 314 & 826 & 37 \\
\hline $\begin{array}{c}\text { with HD- } \\
\text { fatal cases }\end{array}$ & 390 & 479 & 844 \\
\hline $\mathrm{p}$ & $>0,10$ & $>0,01$ & $<0,01$ \\
\hline
\end{tabular}

\section{CONCLUSION:}

HD in severe leptospirosis markedly decreases serum creatinine level and is not effective for serum bilirubin level. The early administration HD is especially benefit - reduces the risk for complications (brain edema and lung edema) and decreases mortality $[1,5,7,8]$.

\section{REFERENCES:}

1. Диков И. и др. Инфекциозни болести, ІІ изд., С., МФ, 1998, 119 - 121.

2. Инфектология, под ред. на Б. Илиев и др., С., МФ, 1998, 392 - 400.

3. Daher EF, et al. Risk factors for death and changing patterns in leptospirosis acute renal failure. Am J Trop Med Hyg, 1999, 61 (4), 630 - 634.

4. Feigin RD, et al. Human leptospiro- sis.. Crit Rev Clin Lab Sci, 1975, 5, 413 467.

5. Ko AI, et al. Urban epidemic of severe leptospirosis in Brazil. Lancet, 1999, 354, $820-825$.

6. Lai KN, et al. Renal lesions in leptospirosis. Aust N Z J Med, 1982, 12, 276 $-279$.

7. Schillinger F, et al. Severe renal forms of leptospirosis. Apropos 6 cases seen in 15 years at one center. Nephrologie, 1999, 109, 94 - 99.

8. Singh SS, et al. Clinico-epidemiolgical study of hospitalized cases of severe leptospirosis. Ind J of Med Res, 1999, 109, $94-99$. 